\title{
Medical kit for single-handed offshore yacht races
}

\author{
Jean Christophe Fimbault ${ }^{1}$, Jean Marc Le Gac ${ }^{2}$, Bruno Barberon ${ }^{1}$, Vincent Lafay ${ }^{1}$, Jean Pierre Auffray ${ }^{1}$ \\ ${ }^{1}$ Société Française de Medecine Maritime, France \\ ${ }^{2}$ Lorient Mer Santé-c3S, Groupe Hospitalier de Bretagne Sud, Lorient, France
}

\begin{abstract}
Background: The medical kit is the basis of medical support in maritime environment; it is defined by international or national regulations and guidelines. For offshore races, rules and recommendations are proposed by national or international sailing federations. Sailing and racing offshore alone presents specificities that sometimes make it difficult to apply the usual recommendations. The epidemiology of single-handed offshore race is dominated by traumatic risks. Medical events are relatively rare because competitors are high-level athletes, generally young and subject to complete medical assessments. The scarcity of available scientific data makes it necessary to choose appropriate methods for developing recommendations. The purpose of this work is to propose a medical kit adapted and applicable to these situations.

Materials and methods: The method used was that of "Professional recommendations by formal consensus of experts" derived from the Rand/UCLA method. After a critical analysis of the literature, a panel of 19 experts having expertise in medicine in maritime environment was gathered from various medical specialties (cardiologist, internist, intensivist and emergency physician, ear-nose-throat physician and general practitioner) and from varied medical activities. They had not declared any direct conflict of interest. Results: A medical kit proposal has been developed. The choice of drugs was based on the analysis of the epidemiology of medical events observed during the last offshore races. The experts' choice was to reduce the quantity of medication and medical devices in order to limit the risk of confusion of medicines and dosages. Drugs with significant side effects or requiring third party monitoring have been removed. Medical devices designed to do an intervention impossible to perform on oneself have also been eliminated. Conclusions: Solo sailing remains a marginal maritime activity with specific risks. The development of single-handed races requires an adaptation of medical support through the development of a specific medical kit and adapted training. The formalised consensus of experts seems to be an appropriate method for developing recommendations in the field of maritime medicine.
\end{abstract}

(Int Marit Health 2019; 70, 4: 220-225)

Key words: medical kit, single handed, offshore yacht races

\section{INTRODUCTION}

The medical kits, with medical training and telemedical advices, are the basis of the medical support in the maritime environment. They are defined by international or national regulations $[1,2]$. Scientific societies have also proposed recommendations mainly in the field of cruising. For offshore yacht races regulations and recommendations are proposed by the national or international federations [3]. The practice of single-handed offshore races presents specificities that sometimes make it difficult to apply the usual recommendations. The epidemiology of single-handed offshore races is dominated by traumatic risks [4, 5]. Medical events, apart from dermatological problems [6], are rare because skippers are high-level athletes, generally young and subject to full medical assessments. The purpose of this work is to propose a medical kit adapted and applicable to this activity.

\section{MATERIALS AND METHODS}

The method used was that of "Professional recommendations by formal consensus of experts" derived from the Rand/UCLA method. After a critical analysis of the literature, a panel of 18 experts (Appendix 1) having expertise in med-

Dr. Jean Christophe Fimbault, Service Medecine Post Urgence, Centre Hospitalier Michel Mazéas de Douarnenez, 85, rue Laennec 29100 Douarnenez, France,

e-mail: jc.fimbault@ch-douarnenez.fr 
icine in maritime environment was gathered from various medical specialties (cardiologist, internist, intensivist and emergency physician, ear-nose-throat physician and general practitioner) and from varied medical activities. They had not declared any direct conflict of interest. The members of the rating group were required to complete the questionnaires submitted to them in their entirety. Next to each item of the questionnaire is placed a numerical scale graduated from 1 to 9 , the value 1 means that the contributor judges the proposal totally inappropriate (or not indicated, or not acceptable), the value 9 means that the contributor judges the proposal is entirely appropriate (or indicated, or acceptable), the values 2 to 8 reflect the possible intermediate situations, the value 5 corresponds to the indecision of the contributor. Two rounds of quotation are carried out. The final ranking of the various proposals was made by calculating the median and the distribution of quotations in strong agreement, relative agreement, indecision, lack of consensus. For the final recommendations, only proposals with strong or relative agreement were selected [7].

\section{RESULTS}

A proposal for a medical kit has been developed (Table 1). The organisation of the kit should allow for intuitive use, possibly using colour-coded modular arrangements, and should include an easily accessible list of content. The drugs are listed Anatomical Therapeutic Chemical (ATC) code (The ATC Classification System) [8] and by generic name followed by the indication for use and whether or not to contact the Telemedical Advice Service (TMAS) before a procedure or administration of a drug.

\section{DISCUSSION}

The choice of the medicines was based on the analysis of the epidemiology of medical events observed during the last offshore races $[4,5,6,9]$. In the same therapeutic class, an analysis of the recent recommendations of learned societies or health authority organisations has made it possible to choose the most relevant medicine according to evidence-based medicine. The experts' choice was to reduce the quantity of medicines and medical devices in order to limit the risks of confusion of the medicines and their dosages, taking into account the limited space and weight allotment on board, and the cost to the skippers for whom it is not a priority. Medicines with significant side effects or requiring special monitoring have been eliminated.

Medical devices designed to perform techniques impossible to execute on oneself have also been eliminated. The other criteria of choice were to promote a compact and light presentation, biochemically and environmentally stable. These recommendations represent the basic minimum endowment, and can be supplemented according to local regulations or requests from race organisers. Skippers with specific pathologies and who have passed the selection tests will have to complete the medical kit by the specific drugs of their pathologies.

\section{CARDIOVASCULAR DRUGS}

They are present in all medical kit for the management of heart failure, acute coronary syndrome or a rhythm disorder. In the case of single handed offshore race, epidemiology $[5,9]$ does not show any major cardiovascular events, although they are still possible. The population of offshore skippers is essentially a young population, high-level athletes, prepared and medically followed before their departure. In addition, if an acute coronary syndrome occurred it would be difficult to start an anti-platelet or anticoagulant treatment with haemorrhagic risks without diagnostic confirmation. Only DL-lysine acetylsalicylate acid in oral sachet was kept [10]. The furosemide, often recommended, has not been retained, the possibility of cardiac or renal decompensation with hydro saline inflation that would not have been revealed before the race is unlikely, the risk in the maritime environment is rather the risk of dehydration.

\section{ANALGESICS}

Level one is represented by paracetamol, for more intense pain paracetamol/nonsteroidal anti-inflammatory drugs combination is recommended [11, 12]. In case of major pain or failure of previous measures, an opioid, morphine sulphate $10 \mathrm{mg}$, should be administered. Given the risk of side effects and the difficulty of performing a titration under good conditions, the choice of the oral route is preferred. To avoid any risk of confusion and overdose, all other medicines have been eliminated as well as presentations involving several medicines.

\section{PSYCHOTROPIC AND SEDATIVE DRUGS}

Psychotropic agents and anxiolytic sedatives, mainly benzodiazepines, are proposed in medical kit for the management and treatment of agitation states, panic attacks or sleep disorders [13]. These drugs can be useful in commercial navigation or crewed sailing but can be dangerous in solitary navigation. They can lead to a decrease in alertness and combativeness and drowsiness, more rarely can they be responsible for paradoxical effects and hallucinations [13]. For all these reasons they have been eliminated from the medical kit.

\section{VASOPRESSIVE CATECHOLAMINES}

The only indication in these situations is the treatment, in emergency, of acute anaphylaxis (stage II and III) of food or drug origin. Under these conditions, the recommended medicine is adrenaline in intramuscular injectable solution with $0.3 \mathrm{mg}$ pre filled syringes in self-injectable device, two 
Table 1. Recommended medicines and equipment on board off-shore racing yachts Medical Support for single-handed Offshore Yacht Races - Medical Kit Inventory*

$X$ indicates that Telemedical Advice Service (TMAS) should be contacted before a procedure or administering a drug.

\begin{tabular}{|c|c|c|c|c|}
\hline \multirow[b]{2}{*}{$\begin{array}{l}\text { Item } \\
\text { no. }\end{array}$} & \multirow[b]{2}{*}{ ATC code } & \multicolumn{2}{|c|}{$\begin{array}{l}\text { LIST OF RECOMMENDED MEDICINES AND EQUIPMENT ON BOARD OFF-SHORE RACING YACHTS } \\
\text { World Health Organization Format }\end{array}$} & \multirow[b]{2}{*}{$\begin{array}{l}\text { Need to } \\
\text { contact } \\
\text { TMAS }\end{array}$} \\
\hline & & $\begin{array}{l}\text { Recommended medicine and } \\
\text { dosage strength representing best pra- } \\
\text { ctice on board off-shore racing yachts }\end{array}$ & Indications on board off-shore racing yachts & \\
\hline \multicolumn{5}{|c|}{ MEDICINES } \\
\hline 1 & A02AE03 & Lansoprazole 30 mg tablet & To treat gastro-oesophageal reflux; to treat ulcer disease & $\mathrm{x}$ \\
\hline 2 & A03AX12 & Phloroglucinol $80 \mathrm{mg}$ & To relieve intestinal or urinary spasms & $\mathrm{x}$ \\
\hline 3 & A06AB02 & Bisacodyl $5 \mathrm{mg}$ tablet & For treatment of constipation & \\
\hline 4 & $\mathrm{~A} 07 \mathrm{CA}$ & Oral rehydration salts sachets & To prevent or treat dehydration & \\
\hline 5 & A07XA04 & Radecadotril $100 \mathrm{mg}$ tablet & Antidiarrheals & \\
\hline 6 & $\operatorname{co5AX}$ & $\begin{array}{l}\text { Haemorrhoid preparations - proprietary } \\
\text { preparation of choice }\end{array}$ & Haemorrhoid preparations & \\
\hline 7 & B02AA02 & Tranexamic acid tablet $500 \mathrm{mg}$ & Treatment of haemorrhage & $x$ \\
\hline 8 & $\mathrm{C} 01 \mathrm{CA} 24$ & Adrenaline auto-injector $0.5 \mathrm{mg}$ & $\begin{array}{l}\text { To raise blood pressure in anaphylaxis; to dilate airways } \\
\text { in severe asthma or anaphylaxis }\end{array}$ & \\
\hline 9 & D01AC02 & Miconazole $2 \%$ ointment (30 g) & To treat fungal skin infections & \\
\hline 10 & D06BA01 & Silver sulfadiazine cream (50 g) & Treatment of burns & \\
\hline 11 & D06BB03 & Acyclovir $5 \%$ cream (10 g) & To treat cold sores & $\mathrm{x}$ \\
\hline 12 & G01AF02 & Clotrimazole 500 mg pessary & To treat vaginal fungal infections & $\mathrm{x}$ \\
\hline 13 & J01XX01 & Fosfomycin tablet & Single dose treatment of uncomplicated acute cystitis in women & $x$ \\
\hline 14 & J01CR02 & Amoxicillin + clavulanate 1000/200 & To treat infections responsive to this antibiotic & $\mathrm{x}$ \\
\hline 15 & J01DD04 & Ceftriaxone $1 \mathrm{~g}$ ampoule & To treat infections responsive to this antibiotic & $\mathrm{x}$ \\
\hline 16 & J01FG01 & Pristinamycin tablets $500 \mathrm{mg}$ & To treat infections responsive to this antibiotic & $\mathrm{x}$ \\
\hline 17 & J01MA02 & Ciprofloxacin 500 mg tablet & To treat infections responsive to this antibiotic & $\mathrm{x}$ \\
\hline 18 & P01AB01 & Metronidazole $400 \mathrm{mg}$ tablet & To treat intestinal infections responsive to this antibiotic & $x$ \\
\hline 19 & H02АВ07 & Prednisone $10 \mathrm{mg}$ tablet & To treat severe asthma; to treat other inflammatory conditions & $\mathrm{x}$ \\
\hline 20 & M01AE01 & Ibuprofen $400 \mathrm{mg}$ tablet & $\begin{array}{l}\text { To treat inflammation; to reduce mild to moderate pain, } \\
\text { especially if associated with inflammation }\end{array}$ & \\
\hline 21 & N01BB02 & Lignocaine gel (6 mL) & Local anaesthetic & \\
\hline 22 & N02AA01 & Morphine sulphate (oral) tablet $10 \mathrm{mg}$ & Opioid analgesic (treatment of moderate to severe pain) & $x$ \\
\hline 23 & N02BA01 & Acetylsalicylic acid 300 mg & $\begin{array}{l}\text { To inhibit formation of blood clots in angina pectoris, } \\
\text { myocardial infarction, stroke }\end{array}$ & $\mathrm{x}$ \\
\hline 24 & N02BE01 & Paracetamol $1 \mathrm{~g}$ tablet & To reduce pain and fever & \\
\hline 25 & N07CA02 & Cinnarizine $25 \mathrm{mg}$ tablet & To prevent and treat motion-sickness & \\
\hline 26 & R06AE07 & Cetirizine tablet $10 \mathrm{mg}$ & Anti-histaminic, anti-allergic & $\mathrm{x}$ \\
\hline 27 & S01AA09 & Tetracycline eye ointment (4 g) & Eye infection & $\mathrm{x}$ \\
\hline 28 & S01AA16 & Rifamycin ophthalmic ointment & Eye infection antiinfective preparations for ophthalmological use & $\mathrm{x}$ \\
\hline 29 & S01CA01 & $\begin{array}{l}\text { Tobramycin/Dexamethasone eye/ear } \\
\text { drops }(10 \mathrm{~mL})\end{array}$ & To treat eye and ear infections & $x$ \\
\hline 30 & S01XA02 & Retinol eye ointment & Topical preparation for repairing eye & $x$ \\
\hline 31 & S02AA12 & Rifamycin ear drop & Ear infection & \\
\hline
\end{tabular}


Table 1. cont. Recommended medicines and equipment on board off-shore racing yachts

\begin{tabular}{lllll}
\hline \multicolumn{3}{c}{ LIST OF RECOMMENDED MEDICINES AND EQUIPMENT ON BOARD OFF-SHORE RACING YACHTS } \\
World Health Organization Format
\end{tabular}

\section{EQUIPMENT}

DRESSING MATERIAL AND SUTURING EQUIPMENT

\begin{tabular}{|c|c|c|}
\hline 32 & Wound closure strips & Adhesive skin closures \\
\hline 33 & Skin stapler $\times 35$ staples & Wound staplers \\
\hline 34 & Stapler remover & Wound staplers \\
\hline 35 & Assorted wound plasters & Adhesive dressing \\
\hline 36 & Adhesive wound dressing $10 \times 10 \mathrm{~cm}$ & Adhesive dressing \\
\hline 37 & Sterile gauze compresses $10 \times 10 \mathrm{~cm}$ & Sterile gauze compresses \\
\hline 38 & Low adherent dressing $10 \times 10 \mathrm{~cm}$ & Gauze dressing with non-adherent surface \\
\hline 39 & Tulle gras dressing & Healing dressing \\
\hline 40 & Haemostatic dressing & Haemostatic agent \\
\hline 41 & Elastic fixation bandage $6 \mathrm{~cm} \times 4 \mathrm{~m}$ & Bandage \\
\hline 42 & Tubular bandage $5,8,10 \mathrm{~cm} \times 10 \mathrm{~m}$ & Bandage \\
\hline 43 & Adhesive surgical tape $2.5 \mathrm{~cm} \times 10 \mathrm{~m}$ & Bandage \\
\hline 44 & Chlorhexidine solution S02AA09 & Antiseptic \\
\hline 45 & Sterile gauze swabs $5 \times 5 \mathrm{~cm}$ & Sterile swabs \\
\hline 46 & Adhesive elastic bandage $7.5 \mathrm{~cm} \times 4.5 \mathrm{~m}$ & Bandage \\
\hline 47 & Cohesive bandage $7.5 \mathrm{~cm} \times 4.5 \mathrm{~cm}$ & Bandage \\
\hline 48 & Trauma tourniquet & Compressing device (bandage), to control bleeding \\
\hline 49 & Gloves non-sterile, disposable & Gloves \\
\hline \multicolumn{3}{|c|}{ INSTRUMENTS } \\
\hline 50 & Bandage scissors (tough cut scissors) & Scissors \\
\hline 51 & Artery clamp & Haemostatic clamp \\
\hline 52 & Splinter forceps (tweezer) & Forceps \\
\hline 53 & Scalpel, sterile, disposable & Disposable scalpels \\
\hline \multicolumn{3}{|c|}{ EXAMINATION AND MONITORING EQUIPMENT } \\
\hline 54 & Stethoscope & \\
\hline 55 & Sphygmomanometer manual & Blood pressure set \\
\hline 56 & Sphygmomanometer automatic & Blood pressure set \\
\hline 57 & Large blood pressure cuff & Blood pressure cuff \\
\hline 58 & Thermometer digital & Thermometer \\
\hline 59 & Pulse oximeter & For monitoring of oxygen saturation \\
\hline 60 & Urine testing strips 10 parameters & Reactive strips for urine analysis \\
\hline 61 & Blood glucose testing kit/25 strips +25 needles & Reactive strips for blood analysis \\
\hline \multicolumn{3}{|c|}{ EQUIPMENT FOR INJECTION, INFUSION AND CATHETERISATION } \\
\hline 62 & Syringes $5 \mathrm{~mL}$ & Equipment for injection \\
\hline 63 & Needle 23 G hypodermic & Equipment for injection \\
\hline 64 & Needle subcutaneous & Equipment for infusion \\
\hline
\end{tabular}

32 Wound closure strip 
Table 1. cont. Recommended medicines and equipment on board off-shore racing yachts

\begin{tabular}{|c|c|c|c|c|}
\hline \multirow[b]{2}{*}{$\begin{array}{l}\text { Item } \\
\text { no. }\end{array}$} & \multirow[b]{2}{*}{ ATC code } & \multicolumn{3}{|c|}{$\begin{array}{l}\text { LIST OF RECOMMENDED MEDICINES AND EQUIPMENT ON BOARD OFF-SHORE RACING YACHTS } \\
\text { World Health Organization Format }\end{array}$} \\
\hline & & $\begin{array}{l}\text { Recommended medicine and } \\
\text { dosage strength representing best pra- } \\
\text { ctice on board off-shore racing yachts }\end{array}$ & Indications on board off-shore racing yachts & $\begin{array}{l}\text { Need to } \\
\text { contact } \\
\text { TMAS }\end{array}$ \\
\hline \multicolumn{5}{|c|}{ GENERAL MEDICAL AND NURSING EQUIPMENT } \\
\hline 65 & \multicolumn{2}{|c|}{ Ethanol $70 \%$ hand cleanser gel $250 \mathrm{~mL}$} & An alternative to hand washing & \\
\hline 66 & \multicolumn{2}{|c|}{ Medical guide } & & \\
\hline 67 & \multicolumn{2}{|c|}{ Medical observation forms } & & \\
\hline 68 & \multicolumn{2}{|l|}{ Cold pack } & To reduce swelling and pain & \\
\hline 69 & \multicolumn{2}{|c|}{ Dental repair kit } & & $\mathrm{x}$ \\
\hline \multicolumn{5}{|c|}{ IMMOBILISATION AND TRANSPORTATION EQUIPMENT } \\
\hline 70 & \multicolumn{2}{|c|}{ Malleable splint } & For immobilizing bone and soft tissue injuries & \\
\hline 71 & \multicolumn{2}{|c|}{ Neck collar, semi-rigid, adjustable } & For neck immobilisation & \\
\hline
\end{tabular}

* List of recommended medicines and equipment as stated in SFMM Consensus Paper on Medical Support for Single handed Off Shore Yacht Races - Medical Kit Inventory

doses must be available and the treatment must be carried out in connection with a TMAS.

\section{DEVICES AND PERFUSION SOLUTION}

The setting up of an intravenous and prolonged infusion seems difficult to achieve in single-handed navigation and not without danger. Emphasis should be placed on the early detection of dehydration states and its correction by electrolytic supply via the digestive tract.

It was not included in these proposals anything which relates to hygiene products (sunscreen, lipstick, dermatological soap, hand protection products and for seat and feet). No survival bag has been proposed as in some other recommendations.

\section{CONCLUSIONS}

The single-handed offshore yacht race remains a marginal practice with specific risks. The development of this type of races requires an adaptation of medical support through the development of a specific medical kit with adapted training. The formal consensus of experts seems to be an appropriate method for the development of recommendations in the field of maritime medicine. The evolution of the medical kits over time is inevitable by adapting to the new epidemiological collections available and according to the evolution of the human constraints of the boats.

\section{REFERENCES}

1. Word Health Organisation. International medical guide for ships: including the ship's medical chest. http://www.who.int/iris/handle/10665/43814.
2. Genton B, D'Acremont V. To prevent and deal with medical problems on board. Rev Med Suisse. 2017; 13(561): 934-937, indexed in Pubmed: 28627850.

3. Nikolić N, Nilson R, Briggs S, et al. A Medical Support in Offshore Racing - Workshop on Medical Kit Inventory in Offshore Yacht Racing, 12-13 May 2017, Lorient, France. Int Marit Health. 2018; 69(3): 214-222, doi: 10.5603/IMH.2018.0035, indexed in Pubmed: 30270422.

4. Nathanson AT, Baird J, Mello M. Sailing injury and illness: results of an online survey. Wilderness Environ Med. 2010; 21(4): 291-297, doi: 10.1016/j.wem.2010.06.006, indexed in Pubmed: 21168780.

5. Jacolot L, Gabart C, Chauve JY. Traumatologie en course au large. Étude épidémiologique de 2008 à 2015. J de Traumatologie du Sport. 2018; 35(1): 60, doi: 10.1016/j.jts.2017.12.018.

6. Mahé $\mathrm{C}$, Jacolot L, Loddé $\mathrm{B}$, et al. Pathologie dermatologique chez des skippers avant et après une transatlantique de haut niveau. Ann de Dermatologie et de Vénéréologie. 2013; 140(12): S476-S477, doi: 10.1016/j.annder.2013.09.263.

7. Fitch K, Bernstein SJ, Aguilar MD, et al. The RAND/UCLA appropriateness method user's manual. Santa Monica (CA): RAND. 2001.

8. Tayebati SK, Nittari G, Mahdi SS, et al. Identification of World Health Organisation ship's medicine chest contents by Anatomical Therapeutic Chemical (ATC) classification codes. Int Marit Health. 2017; 68(1): 39-45, doi: 10.5603/IMH.2017.0007, indexed in Pubmed: 28357835.

9. Carron M, Coulange M, Dupuy C, et al. Preparation and medical follow-up for a single-handed transatlantic rowing race. Int Marit Health. 2017; 68(1): 7-11, doi: 10.5603/IMH.2017.0002, indexed in Pubmed: 28357830.

10. Juliard JM. Antiplatelet and anticoagulant agents during acute coronary syndromes. Réanimation. 2010; 19: 95-102.

11. Russell KW, Scaife CL, Weber DC, et al. Wilderness Medical Society practice guidelines for the treatment of acute pain in remote environments. Wilderness Environ Med. 2014; 25(1): 41-49, doi: 10.1016/j.wem.2013.10.001, indexed in Pubmed: 24462332.

12. Recommandations formalisées d'experts 2010: sédation et analgésie en structure d'urgence. Ann Fr Med Urgence. 2011; 1: 57-71.

13. Martindale the complete drug reference. The pharmaceutical press, London. www.medecinescomplete.com. 
APPENDIX 1. SFMM Position Paper. Medical Support for single handed Offshore Yacht Races - Expert group AUFRAY Jean-Pierre; Société Française de Médecine Maritime, BREST BARBERON Bruno; MD, Société Française de Médecine Maritime, BREST BORGNETTA Marc; MD, Société Française de Médecine Maritime, BREST BRIAND Yann; MD, Société Française de Médecine Maritime, BREST CASAR Dominique; Société Française de Médecine Maritime, BREST CREST Jean-Paul; MD, Société Française de Médecine Maritime, BREST DUBOIS Bertrand; MD, Société Française de Médecine Maritime, BREST FIMBAULT Jean Christophe; MD, Société Française de Médecine Maritime, BREST HOARAU Jean-Michel; MD, Société Française de Médecine Maritime, BREST JACOLOT Laure; MD, Société Française de Médecine Maritime, BREST LAFAY Vincent, MD, Société Française de Médecine Maritime, BREST LE GAC Jean Marc; MD, Lorient Mer Santé -c3S, Groupe Hospitalier de Bretagne Sud, LORIENT LEPLAIDEUR Bruno; MD, Département de Médecine Générale, Collège Sciences de la Santé, Université de BORDEAUX MISERY Laurent; Prof., Société Française de Médecine Maritime, BREST QUELENNEC Baptiste; MD, Société Française de Médecine Maritime, BREST SARDA François; MD, Société Française de Médecine Maritime, BREST SAVARY Olivier; MD, Société Française de Médecine Maritime, BREST VERGNE Muriel; MD, SAMU de Coordination Médicale Maritime Méditerranée, Hôpital Sainte Musse, TOULON 